TAHKIM, Jurnal Peradaban dan Hukum Islam. Vol.1 No.2 (0ktober, 2018) | ISSN : 2597-7962

\title{
HAK HADHANAH DALAM PERCERAIAN KARENA PINDAH AGAMA PERSPEKTIF HUKUM ISLAM
}

\author{
Ramdan Fawzi \\ Fakultas Syariah Universitas Islam Bandung \\ Ramdan.fawzi1985@gmail.com
}

\begin{abstract}
ABSTRAK
Salah satu akibat hukum dari putusnya perkawinan karena perceraian adalah terhadap hak asuh anak yang dalam litelatur fikih disebut hadhanah. Istri mendapatkan legitimasi syariah lebih berhak mendapatkan hadhanah sampai anak usia tujuh tahun. Kendati demikian orang yang melakukan hadhanah memenuhi syarat-syarat yang telah diatur dalam hukum Islam. Undang-undang Nomor 1 Tahun 1974 tentang Perkawinan dan Intruksi Presiden Nomor 1 Tahun 1991 tentang Kompilasi Hukum Islam belum mengatur syarat ke-Islaman bagi yang melakukan hadhanah. Dari hasil penelitian dapat diketahui bahwa jumhur ulama mensyaratkan ke-Islaman bagi orang yang hendak melakukan hadhanah demi tercapainya maksud syariah yaitu menjaga agama (hifzh aldin) dan menjaga keturunan (hifzh al-Nasl).
\end{abstract}

\section{Kata Kunci: Hadhanah, Cerai, Hukum Islam}

\begin{abstract}
One of the legal consequences of a marriage break because of divorce is the custody of children in fiqh litelatur called hadhanah. The wife gets the legitimacy of sharia more entitled to get hadhanah until the seven-year-old child. Even so, those who carry out hadhanah fulfill the conditions set out in Islamic law. Law No. 1 of 1974 concerning Marriage and Presidential Instruction No. 1 of 1991 concerning Compilation of Islamic Law has not set Islamic requirements for those who have hadhanah. From the results of the study it can be seen that the majority of Ulama requires Islamization for people who want to do hadhanah in order to achieve the purpose of sharia, namely maintaining religion (hifzh al-din) and guarding descendants (hifzh al-Nasl).
\end{abstract}

Keywords: Hadhanah, Divorce, Islamic Law

\section{A. PENDAHULUAN}

Kebahagian bagi yang telah melangsungkan pernikahan diantaranya adalah mendapatkan keturunan. Namun demikian, dalam proses membina rumah tangga, laksana bahtera mengarungi lautan yang di dalamnya terdapat badai yang sewaktu-waktu dapat menghantam bahtera rumah tangga. Apabila bahtera tersebut dapat bertahan melewati 
badai rumah tangga maka tujuan pernikahan akan tercapai. Sebaliknya, apabila tidak mampu, maka bahtera rumah tangga akan karam.

Perceraian merupakan kejadian yang sangat tidak diharapkan dalam pernikahan, karena akan memutus ikatan yang sangat kuat dan suci antara kedua belah pihak. Kendati demikian, perceraian diperbolehkan oleh syariat dengan syarat dilakukan dengan acara yang baik. Sebagai dijelaskan dalam al-Quran Surat at-Thalaq [65]: 1

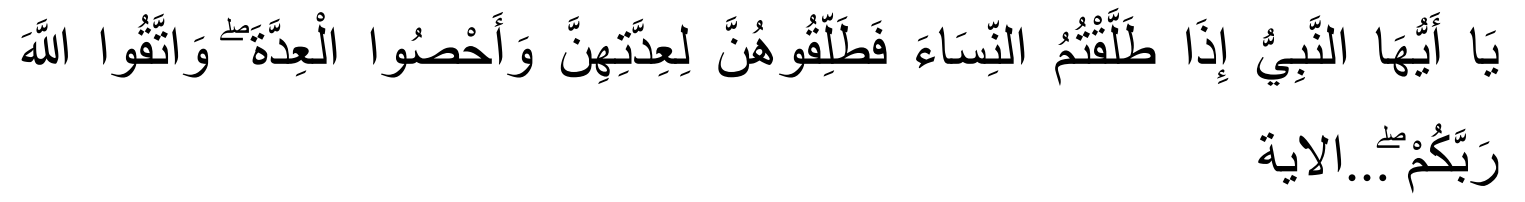

"Hai Nabi, apabila kamu menceraikan isteri-isterimu maka hendaklah kamu ceraikan mereka pada waktu mereka dapat (menghadapi) iddahnya (yang wajar) dan hitunglah waktu iddah itu serta bertakwalah kepada Allah Tuhanmu..."

Menurut Abu Bakar al-Jashshas ayat di atas merupakan khithab kepada Nabi Muhammad dan umatnya terkait waktu menjatuhkan talak kepada istri tidak boleh dalam keadaan haid, dengan katalain harus dalam keadaaan suci dengan tujuan masa iddah yang dilalui tidak terlalu lama dan tidak menzaliminya. ${ }^{1}$

Ayat di atas juga menjadi dasar syari'at atas kebolehan talak atau perceraian dengan berbagai sebab. Diantara sebab-sebab kemungkinan terjadinya perceraian adalah sebagai berikut:

1. Terjadinya nusyuz dari pihak istri yang artinya seorang istri melakukan kedurhakaan terhadap suaminya. Sebagaimana dijelaskan dalam surat al-Nisa [4]: 43

2. Terjadinya nusyuz dari pihak suami sebagaimana dijelaskan dalam surat alNisa [4]:128

3. Terjadinya syiqaq, yaitu percekcokan yang tajam dan terus menerus antara suami dan istri sebagaimana dijelaskan dalam surat al-Nisa [4]: 35

4. Salah satu pihak melakukan perbuatan zinah. Sehingga saling menuduh yang penyelesaiannya dengan cara membuktikan tuduhan dengan cara $l i{ }^{\prime} a n .^{2}$

\footnotetext{
${ }^{1}$ Syekh Abu Bakar al-Jashash, Ahkam al-Qur'an, (Beirut: Dar al-Fikr, 2001) Juz III, hlm. 677.

2 Amiur Nuruddin \& Azhari Akmal Tarigan, Hukum Perdata Islam di Indonesia; Studi Kritis Perkembangan Hukum Islam dari Fikih, UU No. 1 Tahun 1974 sampai KHI, (Jakarta: Kencana, 2012), hlm. 214.
} 
Sementara itu, putusnya perkawinan menurut dalam undang-undang perkawinan No. 1 tahun 1974 pasal 38 disebabkan; a. kematian, b. perceraian, c. keputusan Pengadilan. Hal ini, sama dengan pasal 113 Kompilasi Hukum Islam BAB XVI.

Hal tentang perceraian masih terdapat banyak ayat-ayat dan hadis serta pembahasan dalam kitab-kitab fikih terkait aturan perceraian menurut hukum Islam. Namun pembahasan yang tidak kalah penting adalah akibat yang ditimbulkan oleh perceraian tersebut.

Akibat hukum yang ditimbulkan oleh perceraian sekurang-kurangnya ada tiga. Pertama, akibat hukum terhadap anak. Kedua, akibat hukum terhadap bekas suami atau istri. Ketiga, akibat hukum terhadap harta bersama ${ }^{3}$. Pada penelitian ini fokus mengkaji salah satu akibat hukum perceraian yang pertama, yaitu akibat hukum perceraian terhadap anak.

Islam telah mengatur terkait orang yang paling berhak dalam hadhanah, sebagaimana dijelaskan dalam hadis berikut:

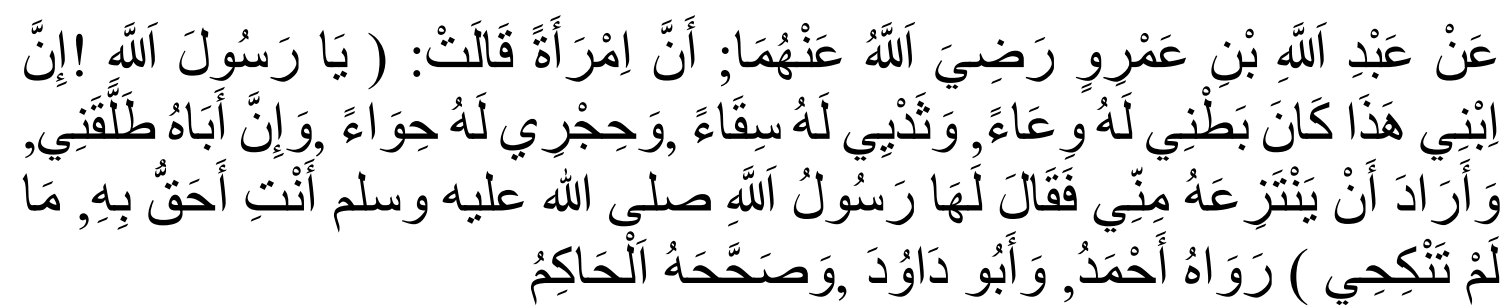

Dari Abdullah Ibnu Amar bahwa ada seorang perempuan berkata: Wahai Rasulullah, sesungguhnya anakku ini perutkulah yang mengandungnya, susuku yang memberinya minum, dan pangkuanku yang melindunginya. Namun ayahnya yang menceraikanku ingin merebutnya dariku. Maka Rasulullah Shallallaahu 'alaihi wa Sallam bersabda kepadanya: "Engkau lebih berhak terhadapnya selama engkau belum nikah."(HR Ahmad dan Abu Dawud. Hadits shahih menurut Hakim)

Berdasarkan hadis di atas, maka dapat diketahui bahwa hak hadhanah diberikan kepada istri (janda). Hadis tersebut juga diperjelas oleh hadis yang lainnya, sebagai berikut:

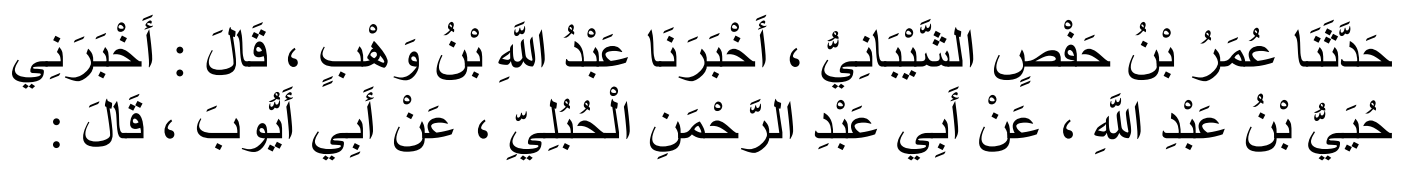

${ }^{3}$ Muhammad Syaifuddin, dkk., Hukum Perceraian, (Jakarta: Sinar Grafika, 2013), hlm. 349. 


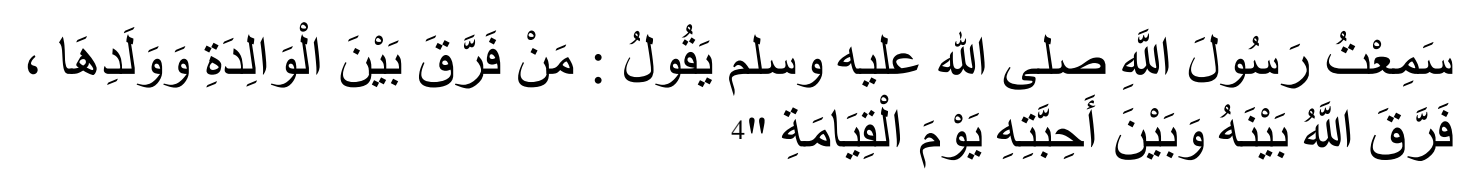

Barangsiapa memisahkan antara ibu dan anaknya, maka Allah akan memisahkan dia dan orang yang dicintainya kelak di hari kiamat.(HR. Imam Tirmidzi)

Hadis dengan narasi khabariyah di atas mengandung makna insya' yaitu larangan memisahkan ibu dengan anaknya. Apabila terjadi, maka mendapat ancaman dari Allah Swt. kelak di hari kiamat akan dipisahkan dengan yang dicintainya.

Memperhatikan kedua hadis di atas, sementara, nampak keberpihakkan kepada ibu (janda) dalam hak hadhanah. Kendati demikian pada hadis di atas tidak mengatur secara jelas terkait keyakinan yang dianut oleh suami atau istri. Tidak menutup kemungkinan salah satu penyebab terjadinya perceraian adalah disebabkan salahsatunya berpindah keyakinan (keluar dari Islam) sehingga pernikahannya batal demi hukum yang salah satu akibat hukumnya adalah terhadap hak asuh anak. Seperti halnya terjadi di Tebing Tinggi. Seorang Istri kembali kepada agama Kristen Protestan dan anak perempuannya berada di bawah kuasa Istri yang di asuh keluarga istri yang sama-sama memeluk Kriten Protestan. Sementara itu anak perempuannya masih balita. ${ }^{5}$ Menurut hadis di atas maka hak hadhanah diberikan kepada ibunya yang beragama Kristen Protestan.

Berdasarkan permasalahan tersebut di atas, perlu tinjauan hukum yang lebih komprehensif terkait hak hadhanah akibat perceraian beda agama.

\section{B. METODE PENELITIAN}

Penelitian tentang hadhanah termasuk wilayah penelitian hukum Islam (fikih), dengan demkian metode yang digunakan adalah metode yuridis normatif. Data-data yang dibutuhkan dalam penelitian ini bersumber pada norma-norma hukum Islam yang terdapat dalam sumber hukum Islam yang pokok dan cabang serta kitab-kitab fikih yang relevan dengan masalah yang diteliti.

\section{PEMBAHASAN}

\section{Pengertian dan Dasar Hukum Hadhanah}

${ }^{4}$ Muhammad bin 'Isa al-Tirmidzi, Jami' al-Tirmidzi, (Beirut: Dar Ihya' alTurats al-'Arabi, t.th). hlm. 1283.

5 Satria Efendi M. Zein, Problematika Hukum Keluarga Islam Kontemporer; Analisis Yuridis dengan Pendekatan Ushuliyyah, (Jakarta: Predana Media, 2004), hlm.168 
Hadhanah etimologis adalah "disamping" atau "dibawah ketiak" sedangkan secara terminologis hadhnah adalah:

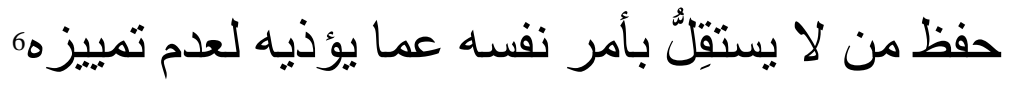

Menjaga anak yang belum bisa mengurusi dirinya sendiri dari hal-hal yang bisa menyakitinya karena belum tamyiz.

Jumhur para ulama telah sepakat bahwa hukum hadhanah, merawat dan mendidik anak adalah wajib. Mencakup masalah ekonomi, pendidikan dan sesuatu yang menyangkut kebutuhan pokok anak. Salah satu dasar hukum wajib hadhanah adalah pemahaman terhadap hadap surat al-Nisa [4]: 9
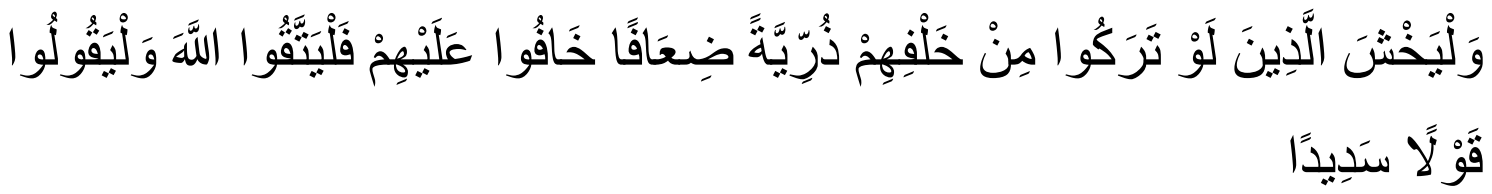

Dan hendaklah takut kepada Allah orang-orang yang seandainya meninggalkan dibelakang mereka anak-anak yang lemah, yang mereka khawatir terhadap (kesejahteraan) mereka. Oleh sebab itu hendaklah mereka bertakwa kepada Allah dan hendaklah mereka mengucapkan perkataan yang benar.

Dan dalam Surat al-Tahrim [66]: 6

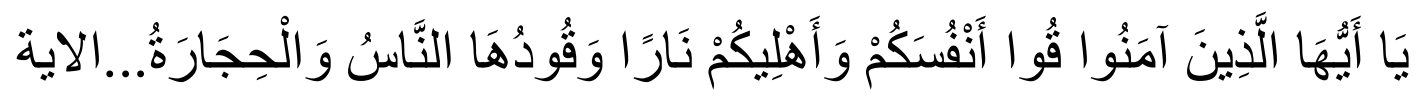

Hai orang-orang yang beriman, peliharalah dirimu dan keluargamu dari api neraka yang bahan bakarnya adalah manusia dan batu...

Ayat-ayat di atas merupakan dasar hukum yang kuat dan tegas tentang kewajiban orangtua dalam mendidik menafkahi agar terhindar dari generasi yang lemah, baik lemah iman, ilmu, ekonomi, fisik dan lain sebagainya.

\section{a. Urgensi Hadhanah}

Pada latar belakang masalah di atas, disebutkan salah satu contoh kasus perceraian yang disebabkan oleh salah satu satu pasangannya berbeda agama. Sementara itu, salah satu akibatnya mengenai hak asuh anak yang sementara itu berada dibawah penguasaan non muslim. Oleh karenanya kepastian hukum Islam mesti memberikan penjelasan.

${ }^{6}$ Muhammad bin Qasim al-Ghazi, Fath al-Qarib al-Mujib, (Jakarta: Dar al-Kutub al-Islamiyyah, 2014), hlm. 149 
Mengingat firman Allah swt. dalam surat al-Nisa [4]: 9 yang diantara subtansinya larangan meninggalkan turunan yang lemah, terutama lemah iman dan juga surat alTahrim [66]: 6 yang salah satu subtansinya adalah kewajiban menjaga keluarga dari siksa api neraka.

\section{b. Batas Usia Hadhanah}

Anak boleh dilepas dari ikatan huquq al-hadhanah sejak usia tamyiz (7 tahun), sedangkan kesiapan anak untuk mandiri dan bertanggung jawab terhadap diri sendiri adalah sejak usia baligh (15 Tahun). Hal ini didasarkan pada hadis sebagai berikut:

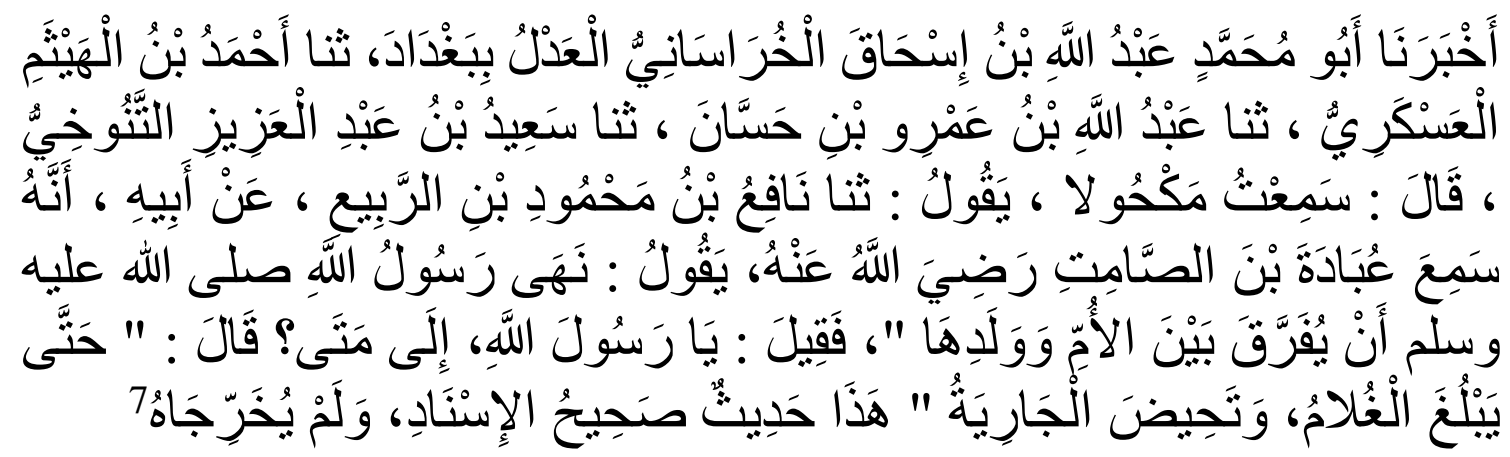

Rasulullah shalallahu 'alaihi wa sallam melarang memisahkan antara ibu dan anaknya. Ada yang bertanya pada beliau, 'Wahai Rasulullah, sampai kapan?' Beliau menjawab, 'Sampai mencapai baligh bila laki-laki dan haidh bila perempuan.' (HR. Imam Hakim)

Imam Nawawi dalam kitab Raudhah dan syarahnya berpendapat bahwa orang di hadhnah (diasuh) adalah setiap anak kecil, orang gila, orang yang cacat daya fikirnya dan orang yang minim sifat tamyiznya sampai pada usia tamyiz. Demikian juga menrut Imam ibnu Hajar dalam Tuhfah, para ulama berbeda pendapat dalam hal batas akhir mengasuh anak kecil ada yang berpendapat sampai usia baligh. Imam al-Mawardi berpendapat batas akhir hadhanah adalah usia tamyiz. Sedangkan pada usia setelahnya hingga baligh adalah hak kafalah. ${ }^{8}$

Menurut Undang-undang Perkawinan Nomor 1 Tahun 1974 pasal 45 diatur sebagai berikut:

1) Kedua orang tua wajib memelihara dan menddidik anak-anak mereka sebaikbaiknya.

${ }^{7}$ Imam Hakim al-Naisaburi, Al-Mustadrak 'ala al-Shahihaini, (Beirut: Dar Kutub al-‘Alamiyyah, t.th) Juz 2, hlm. 55

${ }^{8}$ Sayyid Bakri Syatha, I'anat al-Thalibin, (Dar al-Fikr, t.th), Juz 4, hlm. 101 
2) Kewajiban orang tua yang dimaksud dalam ayat (1) pasal ini berlaku sampai anak itu kawin atau dapat berdiri sendiri kewajiban mana berlaku terus meskipun perkawinan antara kedua orang tua putus.

Berdasarkan pasal 45 Undang-undang Perkawinan di atas, dapat diketahui bahwa batasan memelihara dan mendidik anak adalah samapai anak tersebut menikah atau anak tersebut telah berdiri sendiri dalam istilah fikih disebut tamyiz. Baik kedua orang tua tersebut bercerai ataupun tidak. Sedangkan menurut Kompilasi Hukum Islam pasal 98 batas usia anak yang mampu berdiri sendiri atau dewasa adalah 21 tahun, sepanjang anak tersebut tidak bercacat fisik maupun mental atau belum pernah melangsungkan perkawinan.

Menurut Syekh Muhammad bin Qasim terkait batas usia hadhanah, ia berpendapat sebagai berikut:

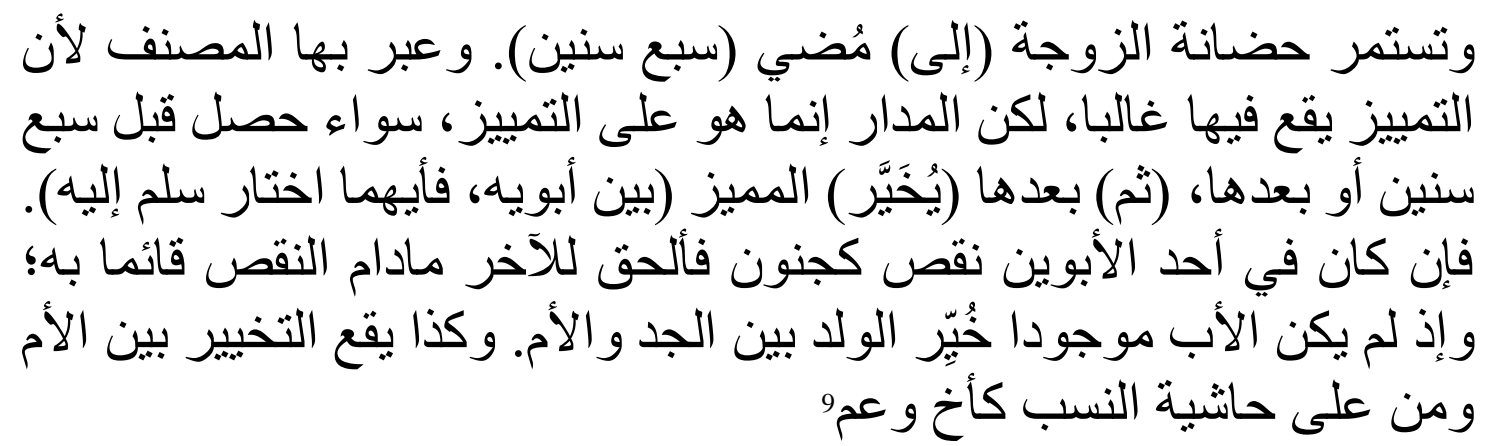

Hak asuh sang istri terus berlangsung hingga melewati usia tujuh tahun. Mushannif mengungkapkan tujuh tahun karena sesungguhnya tamyiz biasanya sudah wujud pada usia tersebut, akan tetapi intinya adalah hingga tamyiz, baik wujudnya sebelum tujuh tahun atau setelahnya. Kemudian setelah itu, anak yang sudah tamyiz tersebut disuruh memilih di antara kedua orang tuanya. Mana yang dia pilih, maka sang anak diserahkan padanya. Lalu, jika salah satu dari kedua orang tuanya memiliki kekurangan seperti gila, maka sang anak diserahkan pada orang tua yang satunya selama sifat kurang tersebut masih ada pada orang tua yang satu itu. Jika ayahnya sudah tidak ada, maka sang anak disuruh memilih di antara kakek dan ibunya. Begitu juga sang anak disuruh memilih di antara ibu dan orang-orang yang masih memiliki hubungan nasab dari jalur samping seperti saudara atau paman dari ayah.

\section{c. Hak dan Syarat-Syarat Melakukan Hadhanah}

Jumhur ulama sepakat bahwa hadhanah hukumnya wajib, namun mereka berbeda pendapat dalam terkait hak hadhanah. Ulama madzhab Hanafi dan ulama madzhab Maliki berpendapat bahwa hak hadhanah adalah hak ibu. Konsekuensi pendapat ini,

${ }^{9}$ Muhammad bin Qasim al-Ghazi, Fath al-Qarib...hlm. 149-150 
seorang ibu bisa menggugurkan hak hadhanah-nya. Sedangkan menurut mayoritas ulama, hak hadhanah adalah hak bersama antara orang tua dan anak. Sehingga apabila terjadi percekcokan atau pertengkaran maka yang didahulukan adalah hak anak. ${ }^{10} \mathrm{Hal}$ ini diatur juga dalam Undang-undang Perkawin Nomor 1 Tahun 1974 pada pasal 41 bahwa apabila perkawinan putus karena perceraian maka akibat itu adalah:

1) Baik ibu atau bapak tetap berkewajiban memelihara dan mendidik anaknya, semata-mata karena kepentingan anak, bilamana ada perselisihan mengenai penguasaan anak Pengadilan memberikan keputusannya

2) Bapak yang bertanggung jawab atas semua biaya pemeliharan dan pendidikan yang diperlukan anak, bilamana bapak kenyataanya tidak dapat memenuhi kebutuhan tersebut, Pengadilan dapat menetukan bahwa ibu ikut memikul biaya tersebut.

3) Pengadilan dapat mewajibkan kepada bekas suami untuk memberikan biaya penghidupan dan atau menentukan sesuatu kewajiban bagi bekas istri. ${ }^{11}$

Adapun bagi yang hendak melakukan hadhanah menurut pengarang kitab Fath al-Qarib maka harus terpenuhi syarat-syarat sebagai berikut:

. (وشر ائط الحضانة سبع): أحدها (العقل)؛ فلا حضانة لمجنونة أطبق جنونُها.

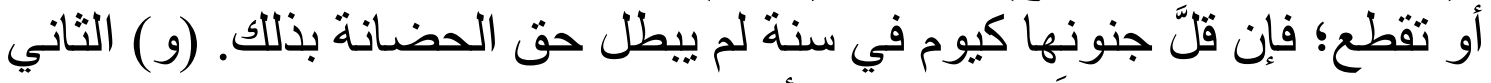

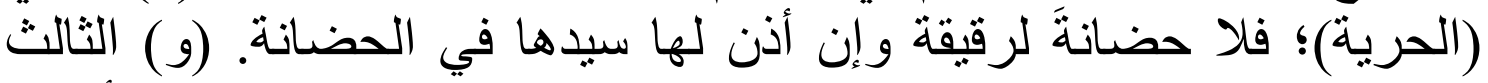
(الدّين)؛ فلا حضانة لكافرة على مسلم. (و) الرابع و الخامس (العفة، والنة والأمانة)

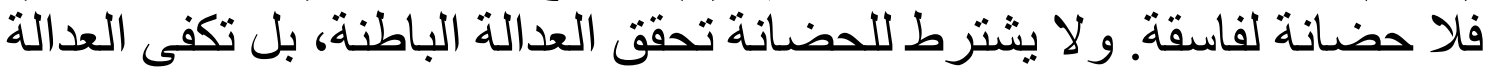

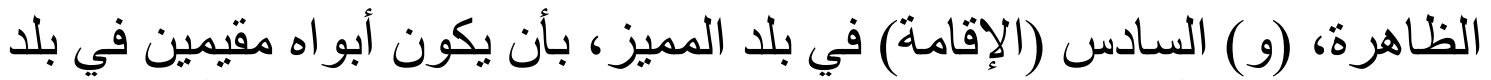

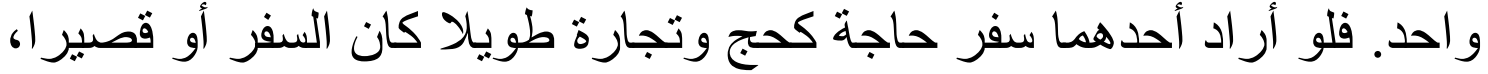

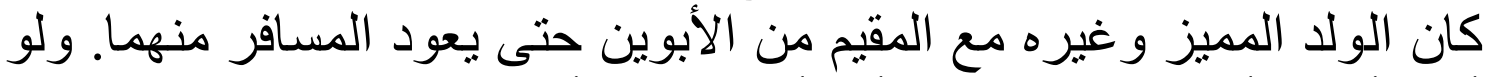

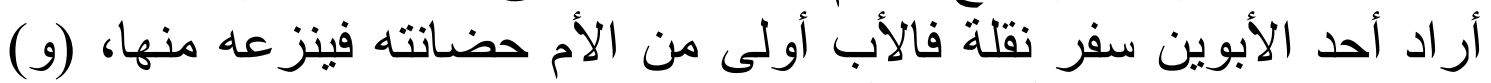
الثرط السابع (الخلو) أي خلو أم المميز (من زوج) ليس اليس من من محارم الطفل.

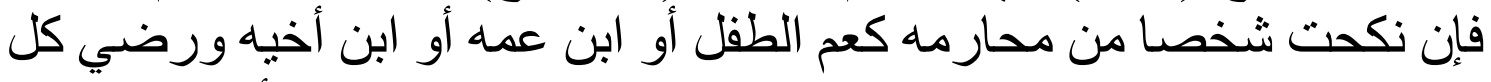

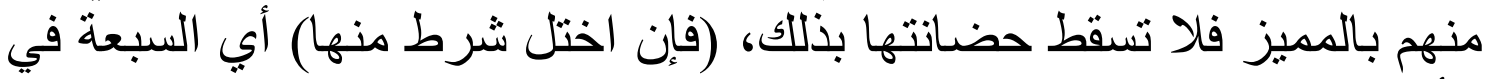

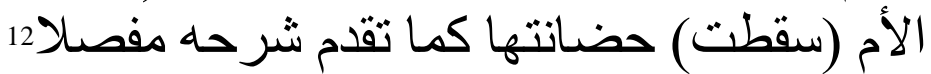

Syarat-syarat hadlanah ada tujuh: Salah satunya adalah berakal. Sehingga tidak ada hak asuh bagi orang gila, baik gilanya terus menerus atau terputus-putus. Lalu, jika gilanya sang istri hanya sebentar seperti sehari dalam satu tahun, maka

${ }^{10}$ Amiur Nuruddin \& Azhari Akmal Tarigan, Hukum perdata Islam ...hlm. 293

${ }^{11}$ Undang-undang Perkawinan Nomor 1 Tahun 1974.

12 Muhammad bin Qasim al-Ghazi, Fath al-Qarib...hlm. 149-150. 
TAHKIM, Jurnal Peradaban dan Hukum Islam. Vol.1 No.2 (0ktober, 2018) | ISSN : $2597-7962$

hak asuhnya tidak batal sebab penyakit tersebut. Yang kedua adalah merdeka. Sehingga tidak hak asuh bagi seorang budak wanita walaupun majikannya memberi izin padanya untuk mengasuh. Yang ketiga adalah agama. Sehingga tidak ada hak asuh bagi wanita kafir atas anak yang beragama islam. Yang ke empat dan kelima adalah 'iffah (terhormat) dan amanah. Sehingga tidak ada hak asuh bagi wanita fasiq. Di dalam hak asuh, sifat adil yang bathin tidak disyaratkan harus nampak nyata, bahkan sudah cukup dengan sifat adil yang dhohir saja. Yang ke enam adalah bermukim di daerah sang anak. Dengan artian kedua orang tuanya muqim di satu daerah. Sehingga, seandainya salah satu dari keduanya ingin bepergian karena ada hajat seperti haji dan berdagang, baik jarak perjalanannya jauh atau dekat, maka anak yang sudah tamyiz atau belum diserahkan kepada orang yang muqim dari kedua orang tuanya hingga yang sedang bepergian telah kembali. Seandainya salah satu dari kedua orang tuanya ingin pindah daerah, maka sang ayah lebih berhak daripada sang ibu untuk mengasuh, sehingga sang anak diambil oleh sang ayah dari tangan sang ibu. Syarat ketujuh adalah sepi, maksudnya sepinya ibu sang anak yang tamyiz dari seorang suami yang bukan termassuk dari mahramnya sang anak. Sehingga, jika sang ibu menikah dengan seorang lelaki dari mahramnya sang bocah seperti paman, anak laki-laki paman, atau anak laki-laki saudara laki-laki sang bocah, dan masing-masing dari mereka rela dengan sang bocah, maka hak asuh ibunya tidak bisa gugur sebab pernikahan. Jika salah satu tujuh syarat tersebut tidak terpenuhi oleh sang ibu, maka hak asuhnya menjadi gugur sebagaimana penjelasan yang telah diperinci.

Sementara itu dalam hukum hukum positif, terkait hadhanah diatur dalam Undang-undang Perkawinan Nomer 1 Tahun 1974 pasal 41 dan pasal 45. Dalam kompilasi Hukum Islam Inpres. No. 1 Tahun 1991 diatur pada pasal 1 (G), pasal 77 (3), pasal 80 (4), pasal 104 (1), pasal 105 ayat a dan b. Dalam Kitab Undang-undang Hukum Perdata diatur pada pasal 319 H dan 319 F. Sedangkan dalam Udang-undang Perlindungan Anak Nomer 23 Tahun 2002 diatur pada pasal 26. Namun demikian pada keseluruhan hukum positif tersebut belum secara rinci mengatur persyaratan khusus bagi yang berhak mendapatkan hadhanah sebagaimana dijelaskan dalam fikih.

\section{d. Hak Hadhanah dalam Perceraian Beda Agama}

Sengketa hak hadhanah kerap terjadi pasca perceraian, hukum Islam telah mengatur dengan jelas orang yang berhak hadhanah sebagaimana dijelaskan dalam hadis berikut:

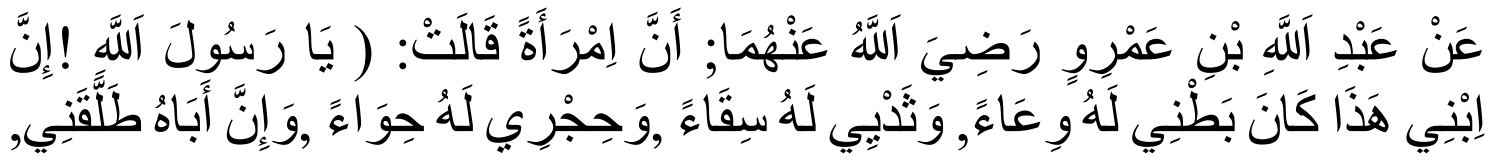




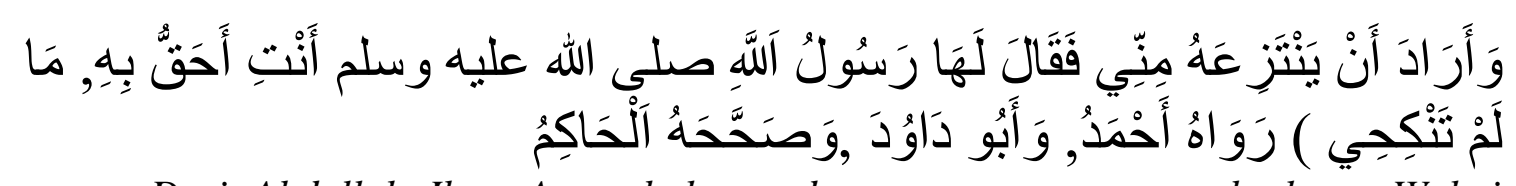

Dari Abdullah Ibnu Amar bahwa ada seorang perempuan berkata: Wahai Rasulullah, sesungguhnya anakku ini perutkulah yang mengandungnya, susuku yang memberinya minum, dan pangkuanku yang melindunginya. Namun ayahnya yang menceraikanku ingin merebutnya dariku. Maka Rasulullah Shallallaahu 'alaihi wa Sallam bersabda kepadanya: "Engkau lebih berhak terhadapnya selama engkau belum nikah."(HR Ahmad dan Abu Dawud. Hadits shahih menurut Hakim)

Berdasarkan hadis di atas, dalam salah satu litelatur fikih al-Syafi'iyyah kitab Fath alQarib karya Syekh Muhammad bin Qasim al-Ghazi, beliau berpendapat:

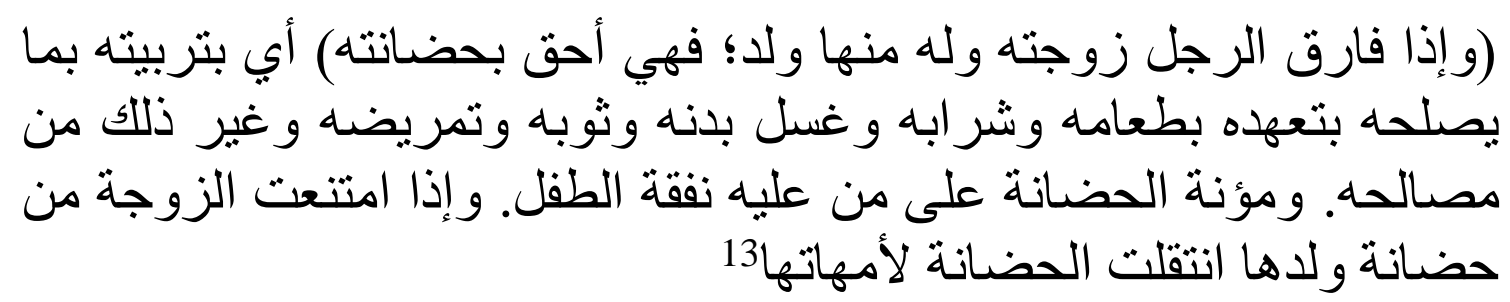

Ketika seorang lelaki bercerai dengan istrinya dan ia memiliki anak dari istri tersebut, maka sang istri lebih berhak untuk merawat sang anak. Maksudnya merawat sang anak dengan sesuatu yang positif padanya dengan mengurusi makanan, minuman, memandikan, mencuci pakaian, merawatnya saat sakit dan hal-hal positif yang lain bagi sang anak. Biaya hadlanah ditanggung oleh orang yang wajib menafkahi anak tersebut. Ketika sang istri enggan merawat anaknya, maka hak asuh berpindah pada ibu sang istri.

Merujuk kepada teks hadis di atas dan pendapat Syekh Muhammad bin Qosim, dan bahwa hak hadhanah diberikan kepada istri (janda). Namun demikian, si istri tersebut harus dapat memenuhi persyaratan yang telah diatur dalam hukum Islam. Dalam kasus salah satu orang tuanya berbeda agama, mayoritas ulama mensyarata orang yang melakukan hadhanah harus beragama Islam, kecuali itu madzhab Hanbali dan sebagian madzhab Hanafi tidak mensyaratkan harus beragama Islam. Demikian juga Syekh Muhammad Abu Zahrah, ia berpendapat tidak mensyaratkan bagi yang melakukan hadhanah terhadap anak yang muslim harus berama Islam. Sebab hak hadhanah seorang ibu terhadap anaknya yang dilahirkan melalui pernikahan secara Islam tidak menjadi gugur disebabkan ibunya berpindah agama, karena anak sangat membutuhkan kasih sayang dan ibu sangat mengerti kebutuhan anaknya. Kecuali anaknya telah tamyiz.

\footnotetext{
${ }^{13}$ Muhammad bin Qasim al-Ghazi, Fath al-Qarib...hlm. 149.
} 
TAHKIM, Jurnal Peradaban dan Hukum Islam. Vol.1 No.2 (0ktober, 2018) | ISSN : $2597-7962$

Namun apabila si ibu terbukti dalam mendidik dan mengurus anaknya ternyata dengan sengaja mempengaruhi anaknya untuk memeluk agamanya (non Islam), maka gugur hak hadhanahnya. ${ }^{14}$

Kendati para ulama terdapat perbedaan pandangan terhadap ke-Islaman sebagai salah syarat mendapat hak hadhahanah. Pendapat masyoritas ulama lebih kuat untuk diimplentasikan, untuk menjaga agama (hifzh al-din) dan menjaga keturunan (hifz alNasl) dari siksa api neraka, sebagaimana dijelaskan dalam surat al-Tahrim [66]: 6

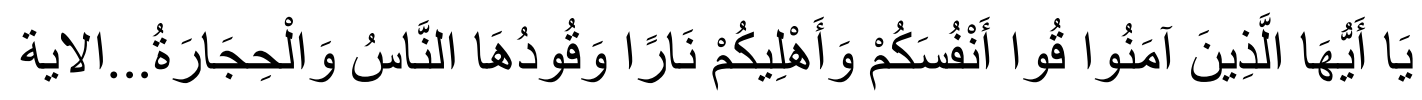

"Hai orang-orang yang beriman, peliharalah dirimu dan keluargamu dari api neraka yang bahan bakarnya adalah manusia dan batu..."

\section{SIMPULAN}

Berdasarkan data yang telah terkumpul dan dianalisis, maka penelitian ini disimpulkan sebagai berikut:

1. Aturan hadhanah dalam hukum Islam dari segi hak, adalah hak bersama antaraorang tua dan anak. Adapun dari segi batas melepas usia hadhanah berpariatif antara tujuh tahun, haid (anak perempuan), lima belas tahun dan sampai menikah. Sedangkan dalam hal orang yang paling berhak mendapat hadhanah adalah istri (janda) setelah terpenuhi syarat-syarat yang telah ditentukan.

2. Hak hadhanah dalam perceraian karena beda agama berdasarkan jumhur ulama, hak hadhanah diberikan kepada orang tua yang beragama Islam.

\section{DAFTAR PUSTAKA}

Al-Jashshash. (2001), Ahkam al-Qur'an, Beirut: Dar al-Fikr.

Al-Ghazi, M. (2014). Fath al-Qarib al-Mujib, Jakarta: Dar al-Kutub alIslamiyyah.

${ }^{14}$ Muhammad Abu Zahrah, al-Ahwal al-Syakhshiyyah, (Dar al-Fikr al-'Arabi, 1948), hlm. 408. 
TAHKIM, Jurnal Peradaban dan Hukum Islam. Vol.1 No.2 (0ktober, 2018) | ISSN : $2597-7962$

Al-Naisaburi, H. (t.th.) Al-Mustadrak 'ala al-Shahihaini, Beirut: Dar Kutub al'Alamiyyah.

Nuruddin, A. \& Tarigan, A.A. (2012). Hukum Perdata Islam di Indonesia; Studi Kritis Perkembangan Hukum Islam dari Fikih, UU No. 1 Tahun 1974 sampai KHI, Jakarta: Kencana.

Syaifuddin, M., dkk., (2013). Hukum Perceraian, Jakarta: Sinar Grafika.

Syatha, S.B. (t.th). I'anat al-Thalibin, Dar al-Fikr.

Tirmidzi, M. (t.th.) Jami’ al-Tirmidzi, Beirut: Dar Ihya' alTurats al-'Arabi.

Zahrah, M.A. (1948). al-Ahwal al-Syakhshiyyah, Dar al-Fikr al-'Arabi.

Zein, S. E. M. (2004). Problematika Hukum Keluarga Islam Kontemporer; Analisis Yuridis dengan Pendekatan Ushuliyyah, Jakarta: Predana Media.

\section{Peraturan Perundang-undangan:}

Intruksi Presiden Nomor 1 Tahun 1991 tentang Kompilasi Hukum Islam Undang-undang Nomor 1 Tahun 1974 tentang Perkawinan Undang-undang Perlindungan Anak Nomer 23 tahun 2002 Kitab Undang-undang Hukum Perdata 